\title{
Experimental validation of a cohesive suspended sediment transport model for two Mexican rivers
}

\author{
Juan Antonio García-Aragón ${ }^{1 *} \mathbb{D}$, Klever Izquierdo-Ayala , María Mercedes Castillo-Uzcanga², \\ Laura Carrillo-Bibriezca ${ }^{3}$ and Humberto Salinas-Tapia ${ }^{1}$
}

\begin{abstract}
Background: The south of Mexico is the least developed part of the country but its basins generate more than 60\% of the country's available water. Though disturbances to the rivers caused by development are still low, there is concern about the environmental health of the rivers. The calculation of the sediment load with a focus in fine fraction, where nutrients are found, is a priority. However, models for suspended sediment transport in large rivers are difficult to formulate because they carry a large amount of cohesive sediments, those cohesive sediments form aggregates or flocs with primary particles that are less than $65 \mu \mathrm{m}$. The hydrodynamic behavior of flocs depends on their size, density and shape, which differs from that of non-cohesive sediments as theirs depends on their interaction with the water column. A classical model to calculate suspended sediment concentration profiles for steady flow conditions is the Rouse equation, which has been extensively validated for non-cohesive suspended sediment. Some authors have demonstrated that when applied in some large rivers in conjunction with non-cohesive settling velocity models it does not perform very well. The difficulty comes from the fact that most of the suspended sediment charge in large rivers is constituted by cohesive sediments.
\end{abstract}

Results: Suspended sediments from Mexico's two largest rivers Usumacinta and Grijalva, with a mean flow rate near river mouth of $2020 \mathrm{~m}^{3} / \mathrm{s}$ and $1150 \mathrm{~m}^{3} / \mathrm{s}$ respectively, were analyzed in a rotating annular flume (RAF). The shear velocity obtained in the field by ADCP was reproduced in the annular flume, the size and shape of flocs were obtained by means of PTV. Settling velocity was also obtained to calibrate a settling velocity model appropriate for cohesive sediments.

Conclusions: The settling velocity model developed for cohesive sediments in conjunction with the Rouse equation allowed the reproduction of suspended sediment concentration profiles for the rivers Usumacinta and Grijalva. The estimated concentration profiles were compared and validated with the measured concentration profiles in the field. Thus, the model obtained through this research can be used to estimate nutrient delivery to the sea from the largest rivers in Mexico.

Keywords: Cohesive sediments, Concentration profiles, PTV, Rotating annular flume, Settling velocity

\footnotetext{
*Correspondence: jagarciaa@uaemex.mx

${ }^{1}$ Instituto Interamericano de Tecnología y Ciencias del Agua, UAEM,

Toluca, Mexico

Full list of author information is available at the end of the article
} 


\section{Background}

The environmental health of a river can be measured by the amount of nutrients it delivers to the sea. Most of these nutrients are carried by the fine fraction in sediments. Nutrients, like Nitrogen (in the form of Nitrates), Phosphorus (in the form of Phosphates) and Silica are hydrophobic and its transport is facilitated in association with the fine fraction of the sediments (HernandezAyon et al. 1993). Phosphorus in its particulate phase can represent $90 \%$ of the total in rivers (Horne and Goldman 1994). The Silica form $\mathrm{SiO}_{2}$ is limiting for Holoplancton growth (Horne and Goldman 1994) and rivers are the main entrance of silica to the ocean (Tréguer and De La Rocha 2013). Particulate nitrogen (PN) is an important way of transport of nitrogen in rivers. In tropical rivers PN represents an average of $30 \%$ of the total nitrogen carried in the river (Lewis et al. 1999).

The fine fraction of sediments is normally transported by large rivers in suspension. Fine sediments in suspension, specifically those with a cohesive character, collide and form flocs due to the shear velocity of the flow and differential settling velocity. Flocs behave in a very different way than non-cohesive sediments. Measuring in situ flocs settling velocities in rivers is difficult with commonly used sediment sampling instruments. In this paper a method based on suspended sediments concentration sampling, and laboratory particle size analysis in a rotating annular flume, is used to obtain flocs' size and settling velocity. The latter are introduced in a settling velocity model, that using the Rouse equation, reproduces the cohesive sediments suspended concentration profiles from the two major rivers in México, Usumacinta and Grijalva. Other authors (Bouchez et al. 2011) have shown that non-cohesive settling velocity models doesn't reproduce well the suspended sediments concentration profiles measured in the Amazon river. Also authors working with the Mississippi river on sediment transport (Jordan 1965; Scott and Stephens 1966) realized that the predicted Rouse number was not equal to the measured Rouse number in a series of vertical profiles sampled in the Mississippi. Similarly, researchers working in the Three Gorges Reservoir in the Yangtze river showed that settling velocities calculated with diameters obtained from a particle size analyzer do not reproduce observed settling velocities indicating the existence of flocculation (Li et al. 2015).

Optical techniques like particle tracking velocimetry (PTV) (Satake et al. 2004) were used in this study to measure particle settling velocities. Flocs were used as tracers in the PTV technique, which also allowed us to measure floc size and shape.

The experimental results were used to validate a settling velocity model for cohesive sediments. In the engineering practice the settling velocity is calculated indirectly by fitting with the Rouse equation (Shi et al. 2003). The contribution of this study is to define a proper cohesive sediment settling velocity model, that in conjunction with the Rouse equation, is able to reproduce suspended sediment concentration profiles measured in the field.

\section{Methods}

Suspended cohesive sediments were sampled in two locations, one in the Grijalva and the other in the Usumacinta river in Centla, Tabasco, upstream from the confluence of both rivers (see Fig. 1). Los Idolos station with coordinates $18^{\circ} 14.07^{\prime} \mathrm{N}$ and $92^{\circ} 40.40^{\prime} \mathrm{W}$, is located in the Grijalva river $14 \mathrm{~km}$ upstream the junction of both rivers at Tres Brazos. Chichicastle station with coordinates $18^{\circ}$ $18.36^{\prime} \mathrm{N}$ and $92^{\circ} 26.69^{\prime} \mathrm{E}$, is located in the Usumacinta river $24 \mathrm{~km}$ upstream the junction at Tres Brazos.

During the months of November and December 2016 a sampling campaign was launched. Suspended sediment concentration profiles were obtained at different water columns in the cross-sections defined at each sampling site. At least three vertical profiles were taken at each sample site, and point samples were obtained with a Van Dorm bottle each $50 \mathrm{~cm}$. In addition, at each sampling site, when taking the vertical samples, $50 \mathrm{~L}$ were collected for the rotating annular flume (RAF) analysis. The sediment characteristics, like floc size variation in time and settling velocity for different floc diameters of the rivers, were obtained in the RAF. The hydrodynamic conditions prevailing in the river were reproduced (same $u^{*}$ ) and the flocculation process was studied during long range experiments in the RAF. The rotating annular flume (RAF) is made of Plexiglass and has a $1.3 \mathrm{~m}$ diameter and a flume cross section of $15 \mathrm{~cm} \times 15 \mathrm{~cm}$ (Fig. 2). The cohesive sediments were analyzed during $5 \mathrm{~h}$ long experiments and images were taken each $15 \mathrm{~min}$. The PTV method was used which implies two procedures. The first one improves image quality through spatial filtering. The second procedure is detecting particles in each pulse.

Experiments in the RAF using samples for the Grijalva and Usumacinta rivers were performed at shear rates similar to those encountered in the field. Table 1 shows the values of shear velocity $\left(\mathrm{u}^{*}\right)$ obtained in the sampling stations of the Grijalva and Usumacinta, with a width of $220 \mathrm{~m}$ and $265 \mathrm{~m}$ respectively, sampled at November and December 2016. In order to calculate $u^{*}$ the fluctuating velocities u'w' were used as shown in the equation below.

$$
u^{* 2}=\overline{u^{\prime} w^{\prime}}
$$

Those velocities were measured in the field by an acoustic doppler current profiler (ADCP). Figures 3 and 4 show representative velocity maps during the sampling days. 


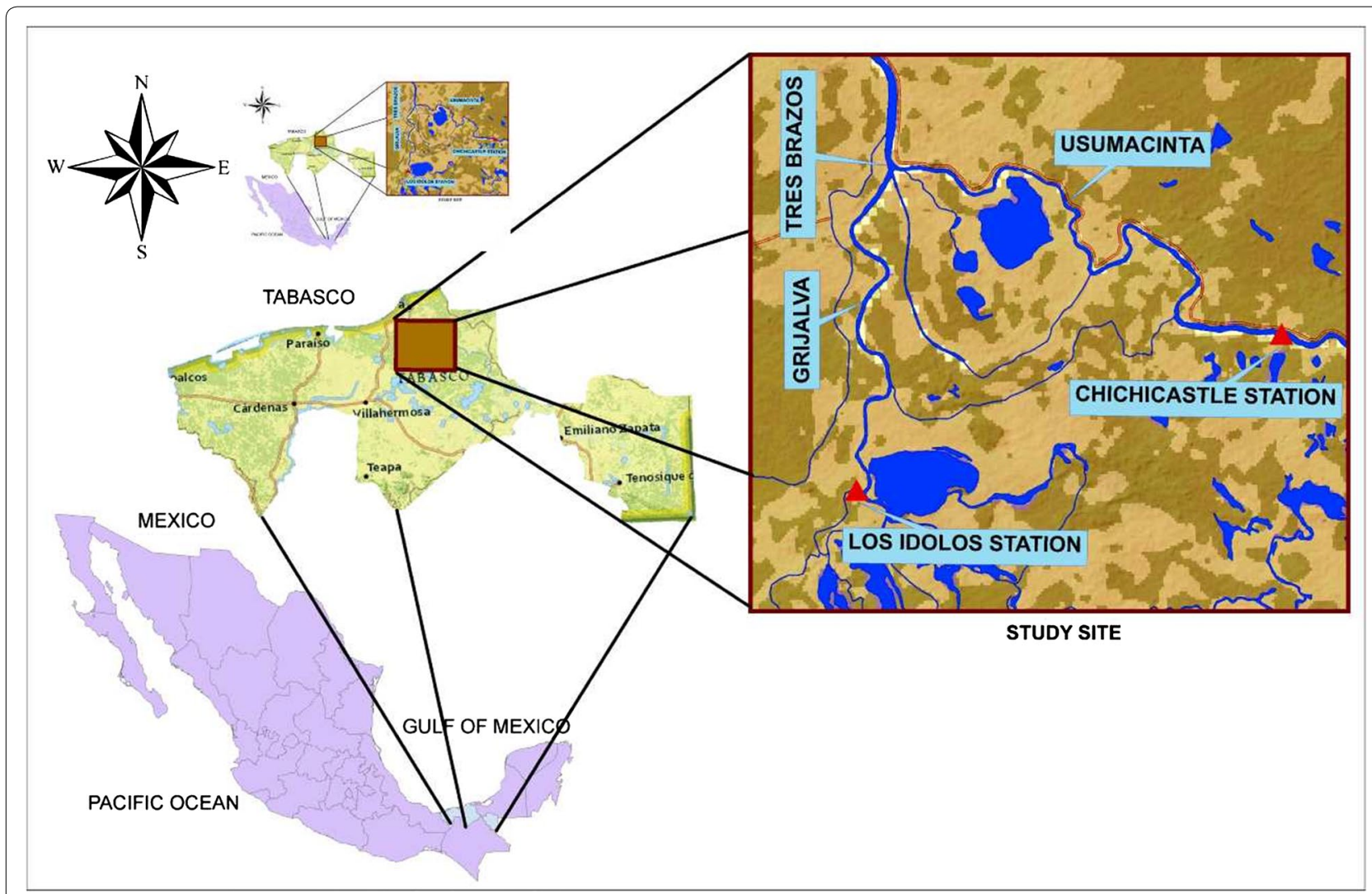

Fig. 1 Location of sampling stations in the Grijalva and Usumacinta rivers

\section{Theoretical settling velocity models}

The main difficulty for the proposal of a settling velocity model for flocs is the adequate definition of their density. Many models have been formulated for floc density (Li and Ganczarczyk 1987), however, in this research the model proposed by Kranenburg (1994) was applied, (Eq. 2)

$$
\rho_{f}-\rho_{w}=\left(\rho_{p}-\rho_{w}\right)\left(\frac{D}{d}\right)^{F-3}
$$

where $\rho_{\mathrm{f}}, \rho_{\mathrm{w}}, \rho_{\mathrm{p}}$ are densities of floc, water and primary particles respectively, $D$ is the floc diameter and $d$ is the primary particles diameter. $F$ is the fractal dimension and the model assumes that the floc is formed of spherical primary particles of equal diameter. The model can be used for non-spherical particles with equivalent diameters.

Using this model, an equation for the settling velocity of flocs has been proposed by Garcia et al. (2018). It has the following form (Eq. 3)

$$
W_{s}=\frac{[13.08(S-1)]^{\frac{1}{2-n}} D^{\frac{F+n-2}{2-n}}}{15^{\frac{1}{2-n}} v^{\frac{n}{2-n}} d^{\frac{F-3}{2-n}}}
$$

where $W_{s}$ is the floc settling velocity in $\mathrm{m} / \mathrm{s}, \mathrm{S}$ is the relative density of primary particles, $v$ is the kinematic viscosity of water, $\mathrm{F}$ is the floc fractal dimension, and $\mathrm{n}$ is a compaction factor that comes from the permeable floc drag coefficient definition.

Using particle tracking velocimetry methods (PTV), Garcia et al. (2014) have shown that a useful relationship for the drag coefficient of a permeable floc has the following form (Eq. 4)

$$
C_{D f}=\frac{15}{R_{e p}^{n}}
$$

where the coefficient $n$ depends on the kind of floc and varies, according to a comparison of results of different authors (Johnson et al. 1996), between 1.1 and 1.25. $R_{e p}$ is the particle Reynolds number defined as

$$
R_{e p}=\frac{W_{s} D}{v}
$$

where $v$ is the kinematic viscosity of the fluid.

As the fractal dimension changes with floc diameter, in this paper a relationship similar to that proposed by 


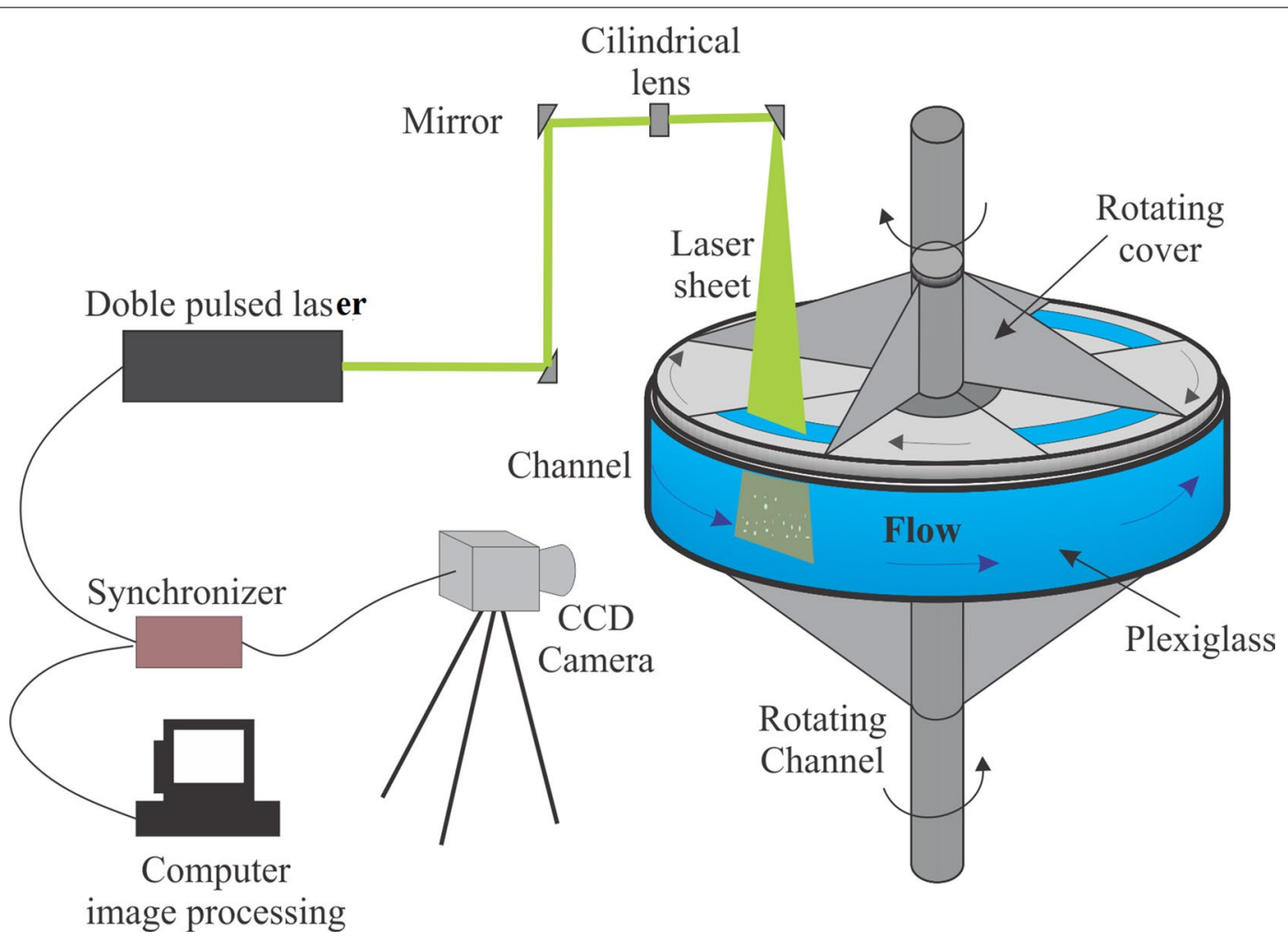

Fig. 2 Rotating annular flume (RAF) and PTV set-up

Table 1 Shear velocity in Usumacinta and Grijalva rivers

\begin{tabular}{lcl}
\hline River & Distance from left bank $(\mathbf{m})$ & $\mathbf{u}^{*}(\mathbf{m} / \mathbf{s})$ \\
\hline Grijalva & 45 & 0.048 \\
& 80 & 0.045 \\
& 165 & 0.036 \\
Usumacinta & 25 & 0.064 \\
& 140 & 0.082 \\
& 215 & 0.065 \\
\hline
\end{tabular}

Garcia et al. (2011) was used to determine the correct fractal dimension and has the following form (Eq. 6)

$$
F=3-\alpha\left[\frac{D}{d}\right]^{\beta}
$$

where $\alpha$ and $\beta$ are constants that depend on the type of cohesive sediment.

\section{Application to suspended load estimation in large rivers}

The Rouse equation can't be used with particle sizes obtained from standard granulometric measurements due to the formation of flocs in large rivers; for that same reason, non-cohesive settling velocity equations will yield incorrect results. Recently researchers working in the Amazon River and tributaries found similar results (Bouchez et al. 2011), their conclusion was that granulometric measurements did not represent the real particle size because cohesive sediments agglomerate to form flocs, and after sampling, these flocs are destroyed and can't be measured appropriately in a laboratory.

The Rouse equation is generally accepted to estimate the suspended sediment profile in stationary flows (Eq. 7), (Chien and Wan 1999),

$$
\left(\frac{C(z)}{C(a)}\right)=\left(\frac{H-z}{z} \cdot \frac{a}{H-a}\right)^{Z_{R}}
$$

where the Rouse number is $Z_{R}=W s / K u^{*}, C(z)$ is the suspended sediment concentration at height $\mathrm{z}$ above bed, $a$ is a reference depth above bed, $\mathrm{H}$ is the flow depth, $K$ is the Von-Karman constant that for low sediment 


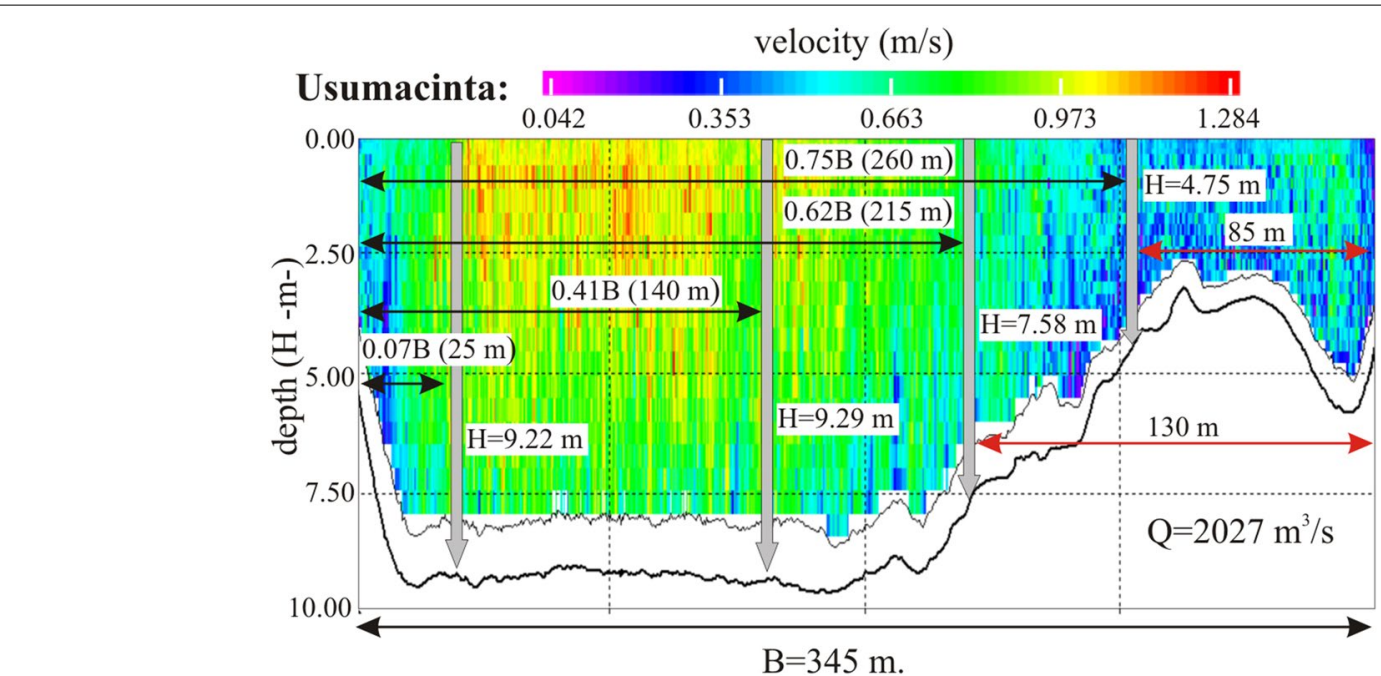

Fig. 3 ADCP results of the Usumacinta river in December 2016 (mean flow $2027 \mathrm{~m}^{3} / \mathrm{s}$ )

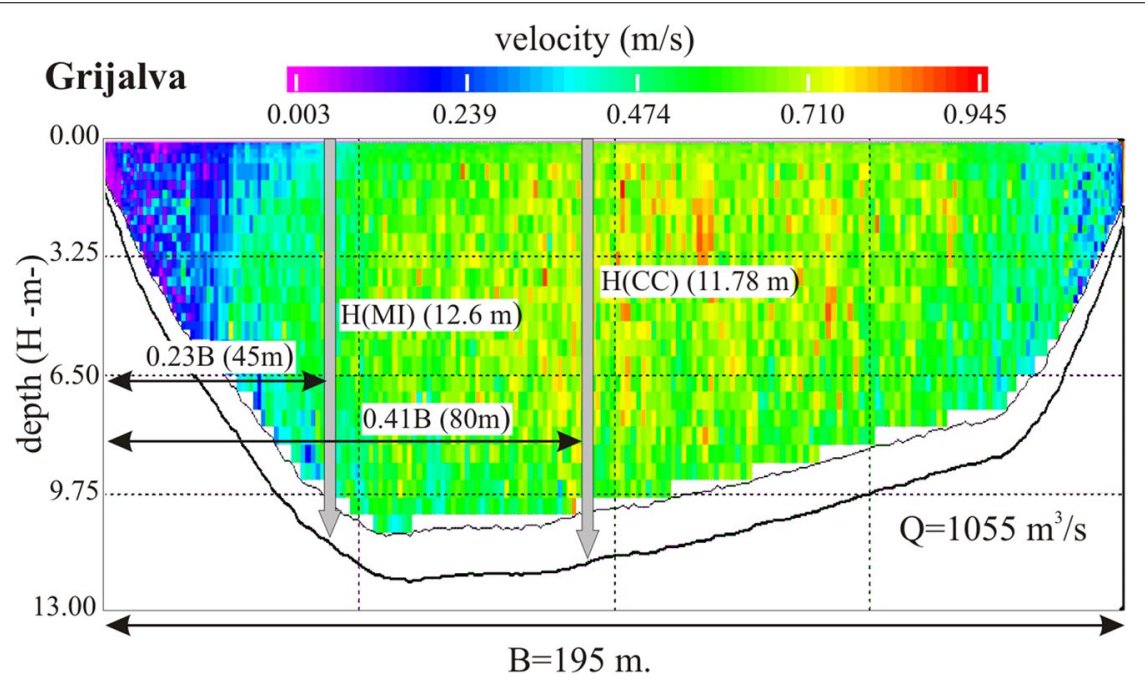

Fig. 4 ADCP results of the Grijalva river in December 2016 (mean flow $1055 \mathrm{~m}^{3} / \mathrm{s}$ )

concentration is equal to 0.4 and $\mathrm{u}^{*}$ is the shear velocity $(\mathrm{m} / \mathrm{s})$.

In this research, Eq. 3 was used to estimate the settling velocity $W s$ and in conjunction with the Rouse equation (Eq. 7) estimate suspended sediment concentration profiles in the Grijalva and Usumacinta rivers.

\section{Results and discussion}

From the sampling of suspended cohesive sediments in the Grijalva and Usumacinta rivers, the following suspended sediment concentration profiles were obtained (Figs. 5 and 6).
In the Grijalva River, the average value of the Rouse number obtained was $\mathrm{Z}_{\mathrm{R}}=0.177$. Which is representative of a small increase of suspended sediment charge near the bottom.

In the Usumacinta River, the average value of the Rouse number obtained was $\mathrm{Zr}=0.065$. This value is representative of near constant suspended sediment charge in the water column.

An average size of flocs in the rivers was determined through images of flocs after $5 \mathrm{~h}$ of experimental runs in the RAF using PTV. Figures 7 and 8 show the statistical values of flocs obtained in large runs at a shear velocity $\mathrm{u}^{*}=0.07 \mathrm{~m} / \mathrm{s}$, the average value in the Usumacinta river 

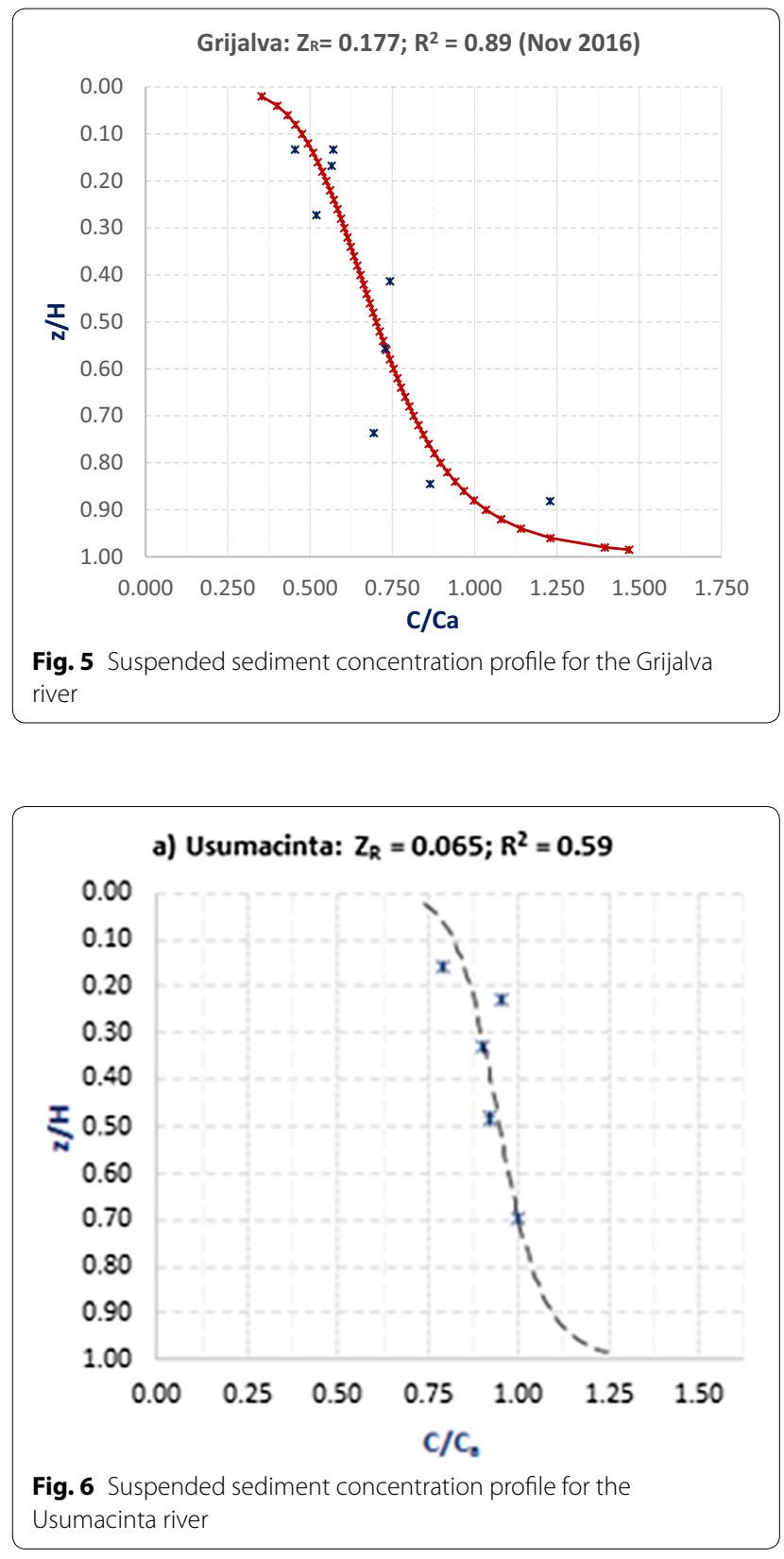

(see Table 1). The mean value of floc size obtained for the Usumacinta river was $260 \mu \mathrm{m}$ (see Fig. 8). Figure 10 shows the values of $\mathrm{D}$ obtained in experiments with controlled $\mathrm{u}^{*}=0.04 \mathrm{~m} / \mathrm{s}$, the average value in the Grijalva river (Table 1). The mean value of floc size obtained for the Grijalva river was $365 \mu \mathrm{m}$.

The values of $\alpha$ and $\beta$ in Eq. 6, 0.07 and 0.72 respectively, were adopted from experiments performed in aquaculture recirculation tanks (Garcia-Aragon et al. 2014).

Figures 7 and 8 show that the average floc size in the Usumacinta varies from $250 \mu \mathrm{m}$ to $270 \mu \mathrm{m}$ in $5 \mathrm{~h}$ long

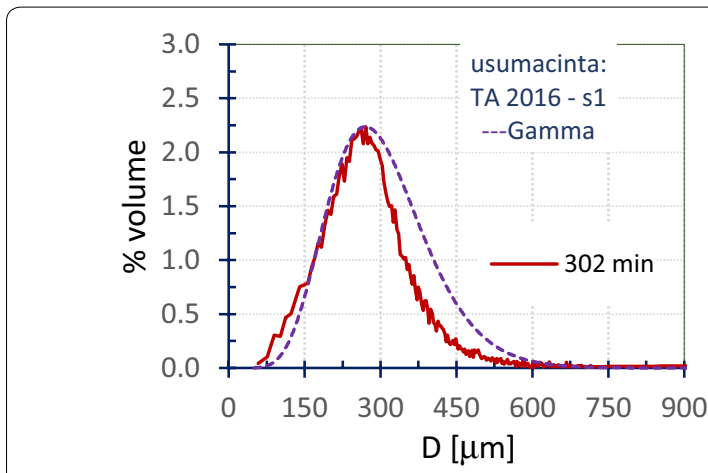

Fig. 7 Floc size distribution at the Usumacinta River from PTV experiments in in the RAF

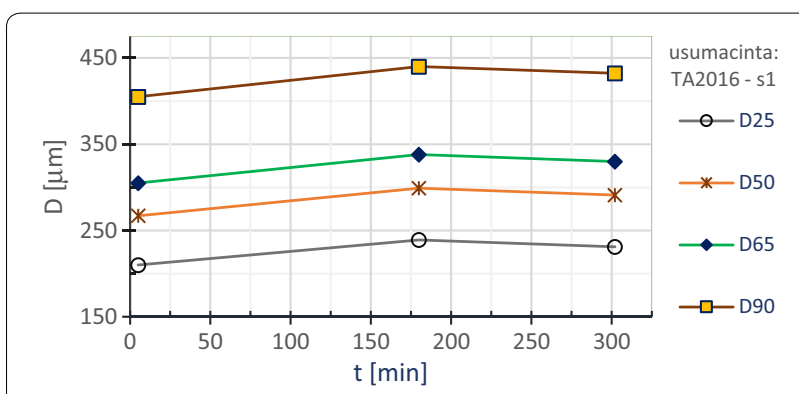

Fig. 8 Floc size variation in time with PTV during RAF experiments for the Usumacinta river

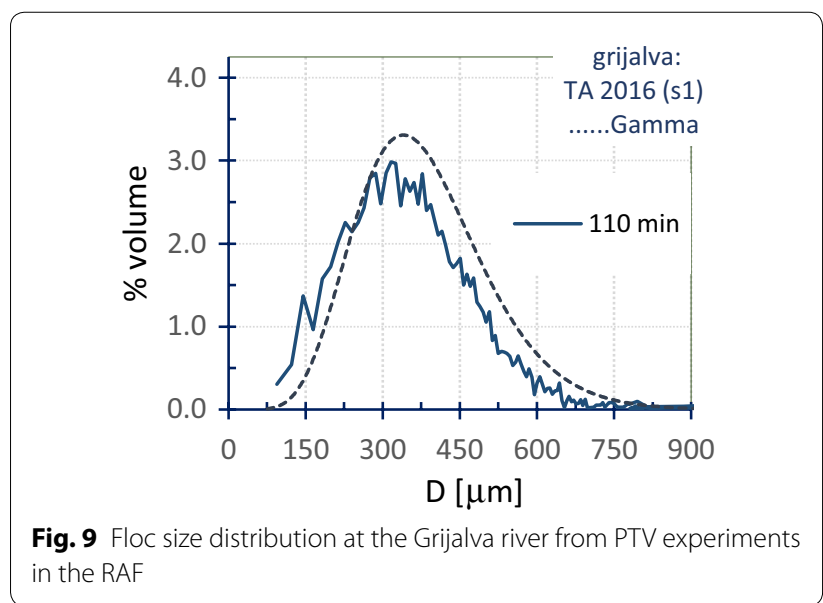

experiments. Also that the largest flocs increase from $410 \mu \mathrm{m}$ to $450 \mu \mathrm{m}$. The floc size distribution at the end of the experiments is well represented by a Gamma distribution with mean $260 \mu \mathrm{m}$.

Figures 9 and 10 show that the average floc size in the Usumacinta varies from $350 \mu \mathrm{m}$ to $375 \mu \mathrm{m}$ in $5 \mathrm{~h}$ long experiments. Also that the largest flocs increase from $535 \mu \mathrm{m}$ to $550 \mu \mathrm{m}$. The floc size distribution at 


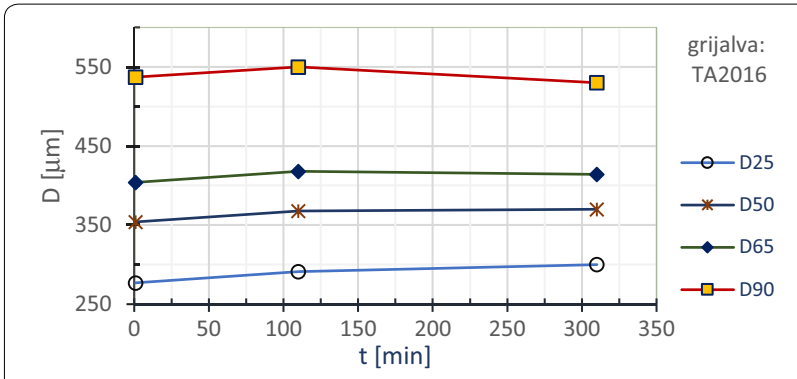

Fig. 10 Floc size variation in time with PTV during RAF experiments for the Grijalva river

$1210 \mathrm{~min}$ of the experiments is well represented by a Gamma distribution with mean value of $365 \mu \mathrm{m}$.

Microscopic images of some representative flocs were obtained with $40 \times$ magnification. An average value of primary particle, after a statistical analysis of 50 flocs images for each river, gave an estimated value of $8 \mu \mathrm{m}$ for the Grijalva river and $3.8 \mu \mathrm{m}$ for the Usumacinta river.

When Eq. 3 is used with the calculated average values of $\mathrm{D}$ and $\mathrm{d}$, and in conjunction with Eq. 6, using values of $\alpha=0.07$ and $\beta=0.72$, the following figures of settling velocity vs. floc diameter were obtained (Figs. 11 and 12). The value of $S$ was chosen as 1.8. The best values of

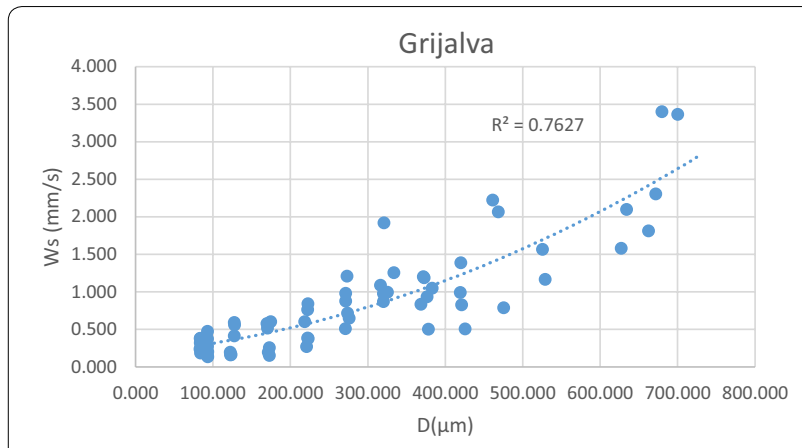

Fig. 11 PTV Measured values of Ws (blue points) and values estimated by Eq. 3 for the Grijalva river

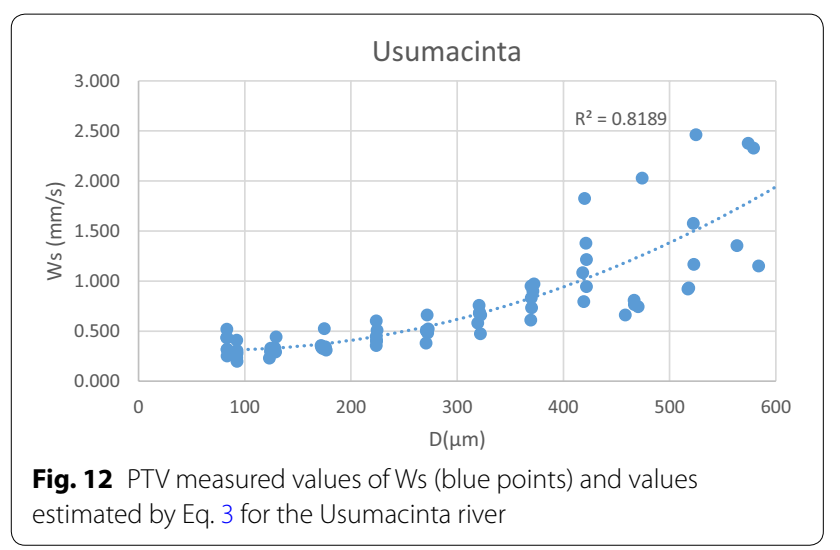

Table 2 Estimated values of Ws by Eq. 5 and corresponding values of $Z_{R}$ for the Usumacinta river

\begin{tabular}{llll}
\hline $\mathbf{D}$ (microns) & $\begin{array}{l}\text { Estimated } \\
\text { Ws-mm/s }\end{array}$ & Estimated $\mathbf{Z}_{\mathbf{R}}$ & Average $\mathbf{Z}_{\mathbf{R}}$ \\
\hline 200 & 0.42 & 0.015 & \\
400 & 1.18 & 0.042 & \\
600 & 1.96 & 0.071 & 0.043 \\
\hline
\end{tabular}

Table 3 Estimated values of Ws by Eq. 5 and corresponding values of $Z_{R}$ for the Grijalva river

\begin{tabular}{llll}
\hline $\mathbf{D}$ (microns) & $\begin{array}{l}\text { Estimated } \mathbf{W}_{\mathbf{s}}- \\
\mathbf{m m} / \mathbf{s}\end{array}$ & Estimated $\mathbf{Z}_{\mathbf{R}}$ & Average $\mathbf{Z}_{\mathbf{R}}$ \\
\hline 200 & 0.90 & 0.06 & \\
400 & 1.54 & 0.11 & \\
500 & 1.68 & 0.15 & 0.11 \\
\hline
\end{tabular}

$\mathrm{n}$, in order to fit the measured data, were $\mathrm{n}=1.10$ and $\mathrm{n}=1.15$, for the Grijalva and Usumacinta rivers respectively, which represents the presence of strong flocs.

Tables 2 and 3 show the estimated values of Ws according to Figs. 11 and 12, for floc sizes similar to the averages of $365 \mu \mathrm{m}$ in the Grijalva river and $260 \mu \mathrm{m}$ in the Usumacinta river.

Table 2 shows that the estimation of $Z_{R}$ for the Usumacinta river, using the proposed model, is very close to that measured in the field (see Fig. 5) $Z_{R}=0.065$. The values of $\mathrm{D}$ used were close to the average floc size determined by PTV. The results show that the concentration profile in the Usumacinta river is almost constant in the flow depth.

Table 3 shows that the estimation of $Z_{R}$ for the Grijalva river, using the proposed model, is also close to the value measured in the field, because the average measured $Z_{R}$ (see Fig. 2) was 0.177 . This value shows the same trend measured in the field, an increase of concentration near the bottom of the river, opposite to the case of the Usumacinta river.

These results indicate that flocs coming from both rivers are strong flocs, which is logical because shear rates at the Usumacinta and Grijalva rivers are large.

For comparison data from the Amazon river at stations Obidos and Iracema are presented in Table 4 (Bouchez et al. 2011) with the results from this research at stations Chichicastle and los Idolos.

It is observed in Table 4 that shear velocity $\mathrm{u}^{*}$ in the Amazon river at station Iracema is similar to that of the Usumacinta river at Chichicastle. This shows that Usumacinta river turbulence is very high. However the settling velocity for the average size of flocs in the Usumacinta river is very low compared to Amazon river 
Table 4 Comparison of measured values in the Amazon river with this research results

\begin{tabular}{|c|c|c|c|c|c|c|}
\hline Station & River & Date & Flow depth $\mathrm{H}(\mathrm{m})$ & $Z_{R}$ & $\begin{array}{l}u^{*} \\
m / s\end{array}$ & $\begin{array}{l}\text { Ws } \\
\mathrm{mm} / \mathrm{s}\end{array}$ \\
\hline Obidos & Amazon & $\begin{array}{l}\text { March } \\
2006\end{array}$ & 67 & 0.24 & 0.10 & $9.8^{\mathrm{a}}$ \\
\hline Iracema & Amazon & $\begin{array}{l}\text { March } \\
2006\end{array}$ & 50 & 0.19 & 0.07 & $3.9^{\mathrm{a}}$ \\
\hline Chichicastle & Usumacinta & $\begin{array}{l}\text { December } \\
2016\end{array}$ & 11 & 0.043 & 0.07 & 0.42 \\
\hline Los Idolos & Grijalva & $\begin{array}{l}\text { November } \\
2016\end{array}$ & 9 & 0.11 & 0.04 & 1.54 \\
\hline
\end{tabular}

${ }^{a}$ Estimated values from concentration profiles

flocs. This is an indication of larger flocs in the Amazon river. Unfortunately Bouchez et al. (2011) were unable to measure floc sizes. We can infer the presence of large flocs in the Amazon by comparing the $Z_{R}$ values. In the Amazon river $Z_{R}$ is large indicating large concentrations near the bottom and large sedimentation rates. It should be indicated that flow rates and flow depths in the Amazon river are very much larger than those of the Usumacinta and Grijalva rivers (one order of magnitude) and also are suspended sediment concentrations. However the high turbulence in the Usumacinta river can cause floc breakage explaining the lower size of flocs (hence lower settling velocity) in the Usumacinta river. Respecting to the Grijalva river the shear velocity is lower than those of the Usumacinta and the Amazon. This explains the larger settling velocity of its flocs compared to those of the Usumacinta river. However this settling velocity is lower than that of the Amazon river flocs especially at Obidos station. This is related to the larger values of $Z_{R}$ at the Amazon river and consequently larger floc settling velocities.

The average size in the Grijalva river flocs is similar to the one found in the Po river Delta which is $370 \mu \mathrm{m}$ (Fox et al. 2004). In this Delta large flocculation was shown to exist and the shear velocity is low due to hydrodynamic conditions. One of the few work done in measuring in situ floc size is the research developed at the Dollard estuary (Holland) by means of underwater video cameras-UVC (Van der Lee 2000). He found flocs size varying from 100 to $300 \mu \mathrm{m}$ with densities varying from 1500 to $1100 \mathrm{~kg} / \mathrm{m}^{3}$ for a concentration of $350 \mathrm{mg} / \mathrm{L}$. Using Kranenburg equation for the average size of the Grijalva river $365 \mu \mathrm{m}$ the floc density is $1150 \mathrm{~kg} / \mathrm{m}^{3}$ which is similar to the lower end of Dollard estuary. The somewhat larger floc density comes from the lower concentration at the Grijalva river (which is on average in the November sampling of $30 \mathrm{mg} / \mathrm{L}$ ) and the larger shear rates of the Grijalva river compared to Dollard estuary.
The settling velocity in the Usumacinta river is similar to the values found by Maa and Kwon (2007) in the York river. They obtained an average value of settling velocity of $0.5 \mathrm{~mm} / \mathrm{s}$ for $50 \mathrm{mg} / \mathrm{L}$ of suspended sediment concentration (the average value of concentration for the Usumacinta river in December 2016 was $50 \mathrm{mg} / \mathrm{L}$ ). Unfortunately they didn't measure floc sizes. Xia et al. (2004) measured floc sizes and settling velocities in the Pearl river estuary, China using LISST and found very small flocs (size under $96 \mu \mathrm{m}$ ). They found an interesting relationship between excess floc density and floc size: $\rho_{\mathrm{f}-} \rho_{\mathrm{w}=47233 . \mathrm{D}}^{-1.58}(\mathrm{D}$ in $\mu \mathrm{m})$. Using this relationship the average floc density at the Usumacinta river for $260 \mu \mathrm{m}$ would be $1015 \mathrm{~kg} / \mathrm{m}^{3}$. Using the Kranenburg equation (Eq. 2) the floc density for the average particle size of the Usumacinta river is $1120 \mathrm{~kg} / \mathrm{m}^{3}$. The difference can be attributed to the smaller sizes of Pearl river estuary (where the equation was validated) compared to those of the Usumacinta river.

With respect to the primary particle diameter to be used in these models a useful relationship has been presented by Maggi (2013) after comparing flocs of different composition mineral, biomineral and biological particles. He found that the primary particle diameter $d$ is related to the floc density as: $d=-(2.76 \mathrm{e}-9)$ $\rho_{\mathrm{f}}+7.32 \mathrm{e}-6$. Using the latter formula the primary particle diameter for the average floc size at the Usumacinta river would be $4.2 \mu \mathrm{m}$ and for the the Grijalva river $4.1 \mu \mathrm{m}$. The former is very similar to the one used in this research for the $Z_{R}$ calculations in the Usumacinta river and the latter almost half the one used for the Grijalva river.

\section{Conclusions}

A method to calculate sediment concentration profiles for rivers with a large cohesive suspended sediment load was presented. The method uses a settling velocity model for cohesive sediments which allows the proper 
determination of the Rouse number $Z_{R}$. This method contrary to traditional engineering practice introduce the cohesive character of suspended sediments in large rivers. The contribution of this study is the definition of this cohesive sediment settling velocity model and its validation with suspended sediment concentration profiles measured in the field.

The necessary data to use this model is, the average floc size which must be obtained by laboratory experiments in a rotating annular flume (RAF), the average shear rate of the flow obtained in the field by devices like ADCP, and floc characteristics. These characteristics are fractal dimension and size of primary particles. The expression to calculate fractal dimension in this research was validated experimentally with flocs coming from aquaculture tanks, more research is needed for other applications. In order to calculate floc density, the Kranenburg formula was used, which requires a careful analysis of the primary particles' diameter. The degree of floc compaction represented by the parameter $\mathrm{n}$ could be obtained by comparing estimated values of the settling velocity with measured values.

The amount of nutrients carried by the river can be associated with the fine fraction of suspended sediments which allow an analysis of the environmental health of the river. In order to define the total annual transport of sediments, it is necessary to perform a monthly analysis, the data presented in this paper is for large flow rates November and December in the Usumacinta and Grijalva rivers.

\section{Abbreviations}

ADCP: acoustic doppler current profiler; LISST: laser in situ settling tube; PN: particulate nitrogen; PTV: particle tracking velocimetry; RAF: rotating annular flume; UVC: underwater video camera.

\section{Authors' contributions \\ KIA performed the sampling of sediments and help measure concentrations, MMCU helped in the laboratory analysis of sediments, LCB helped in the use of the ADCP and interpretation of data, HST helped in the application of the settling velocity model to the data and in the experiments with RAF and JAGA helped in the interpretation of experimental data, the model formulation and results analysis. All authors read and approved the final manuscript.}

\section{Author details}

1 Instituto Interamericano de Tecnología y Ciencias del Agua, UAEM, Toluca, Mexico. ${ }^{2}$ El Colegio de la Frontera Sur, unidad Villahermosa, Villahermosa, Tabasco, Mexico. ${ }^{3}$ El Colegio de la Frontera Sur, unidad Chetumal, Chetumal, Quintana Roo, Mexico.

\section{Acknowledgements}

Not applicable.

\section{Competing interests}

The authors declare that they have no competing interests.

\section{Availability of data and materials}

The data sets used and/or analyzed during the current study are available from the corresponding author on reasonable request.
Consent for publication

Not applicable.

Ethics approval and consent to participate

Not applicable.

Funding

The second author thanks the Mexican Government funding agency (CONACYT) for the doctoral studies scholarship (Grant No. 182011).

\section{Publisher's Note}

Springer Nature remains neutral with regard to jurisdictional claims in published maps and institutional affiliations.

Received: 24 September 2018 Accepted: 28 March 2019

Published online: 16 April 2019

\section{References}

Bouchez J, Metivier F, Lupker M, Maurice L, Perez M, Gaillardet J, France-Lanord C (2011) Prediction of depth-integrated fluxes of suspended sediment in the Amazon River: particle aggregation as a complicating factor. Hydrol Process 25:778-794

Chien N, Wan Z (1999) Mechanics of sediment transport. ASCE press, Reston, p 913

Fox JM, Hill PS, Milligan TG, Boldrin A (2004) Flocculation and sedimentation on the Po River Delta. Mar Geol 203:95-107

Garcia-Aragon JA, Droppo I, Krishnappan B, Trapp B, Jaskot C (2011) Experimental assessment of Athabasca River cohesive sediment deposition dynamics. Water Qual Res J Can 46(1):87-96

Garcia-Aragon JA, Salinas-Tapia H, Moreno-Vega J, Diaz-Palomarez V, TejedaVega S (2014) A model for the settling velocity of flocs; application to an aquaculture recirculation tank. Int J Comp Methods Exp Meas 2(3):313322. https://doi.org/10.2495/cmem-v2-n3-313-322

Garcia-Aragon JA, Salinas-Tapia H, Diaz-Palomarez V, Izquierdo-Ayala K (2018) Optical methods applied to hydrodynamics of cohesive sediments. In: Daniela M (ed) Applications in water systems management and modelling. IntechOpen, London, pp 111-129

Hernandez-Ayon JM, Galindo Bect B, Florez-Baez P, Alvarez-Borrego S (1993) Nutrient concentrations are high in the turbid waters of the Colorado River Delta. Estuar Coast Shelf Sci 37:593-602. https://doi.org/10.1006/ ecss.1993.1075

Horne AJ, Goldman CR (1994) Limnology, 2nd edn. McGraw Hill, New York

Johnson CP, Xiaoyan LI, Logan BE (1996) Settling velocities of fractal aggregates. Environ Sci Technol 30:1911-1918

Jordan PR (1965) Fluvial sediment of the Mississippi River at St. Louis, Missouri. USGS Water-Supply Paper 1802. http://pubs.er.usgs.gov/djvu/WSP/wsp18 02.djvu. 1965

Kranenburg C (1994) The fractal structure of cohesive sediment aggregates. Estuar Coast Shelf Sci 39:1665-1680

Lewis WM, Melack JM, McDowell WH, McClain M, Richey JE (1999) Nitrogen yields from undisturbed watersheds in the Americas. Biogeochemistry 46:149-162. https://doi.org/10.1007/BF01007577

Li DH, Ganczarczyk JJ (1987) Stroboscopic determination of settling velocity, size and porosity of activated sludge flocs. Water Res 21(3):157-262

Li W, Wang J, Yang S, Zhang P (2015) Determining the existence of the fine sediment flocculation in the Three Gorges Reservoir. J Hydraul Eng 141(2):05014008

Maa JPY, Kwon JI (2007) Using ADV for cohesive sediment settling velocity measurements. Estuar Coast Shelf Sci 73:351-354

Maggi F (2013) The settling velocity of mineral, biomineral and biological particles and aggregates in water. J Geophys Res 118:22118-22132

Satake S, Kunugi T, Sato K, Ito T (2004) Digital holographic particle tracking velocimetry for 3-D transient flow around an obstacle in a narrow channel. Opt Rev 11:162-164

Scott CH, Stephens HD (1966) Special sediment investigations: Mississippi river at St. Louis, Missouri, Water Supply Paper 1819- J USGS. https://doi. org/10.3133/wsp1819J 
Shi Z, Zhou HJ, Eittrein SL, Winterwerp JC (2003) Settling velocities of fine suspended particles in the Changjiang Estuary, China. J Asian Earth Sci 22(3):245-251

Tréguer PJ, De La Rocha CL (2013) The world ocean silica cycle. Annu Rev Mar Sci 5(1):477-501. https://doi.org/10.1146/annurev-marine-121211-172346
Van der Lee WTB (2000) Temporal variatiomof floc size and settling velocity in the Dollard estuary. Cont Shelf Res 20:1495-1511

Xia XM, Li Y, Yang H, Wu CY, Sing TH, Pong HK (2004) Observations on the size and settling velocity distributions of suspended sediment in the Pearl River Estuary, China. Cont Shelf Res 24(2004):1809-1826
Submit your manuscript to a SpringerOpen ${ }^{\circ}$ journal and benefit from:

- Convenient online submission

- Rigorous peer review

- Open access: articles freely available online

- High visibility within the field

- Retaining the copyright to your article

Submit your next manuscript at springeropen.com 